\title{
ANALISIS APLIKASI JADWAL PERKULIAHAN BERBASIS ANDROID
}

\author{
Daniswara Galuh Sukmandari \& Totok Sukardiyono \\ Universitas Negeri Yogyakarta \\ e-mail: 10520244064@student.uny.ac.id
}

\begin{abstract}
The research aims to analyze the software quality of mobile application course schedule based on ISO 25010 software quality standard which includes of functional suitability, compatibility, usability and performance efficiency.The method used in this research was Research and Development $(R \& D)$ with waterfall model. The result of this research was the course schedule application fulfill the standard of software quality based on ISO 25010. Functional suitability testing obtained 100\% value which means that the function of application ran well. Compatibility testing obtained $100 \%$ value. Usability testing obtained 79,63\% value with category of Eligible. Performance efficiency testing obtained average respone time of launching 2,048 seconds and 0,095 seconds in average of rendering time.
\end{abstract}

Keywords: schedule, mobile application, Android, ISO 25010.

\begin{abstract}
ABSTRAK
Penelitian ini bertujuan untuk menganalisis kualitas perangkat lunak pada aplikasi mobile jadwal perkuliahan berdasarkan standar kualitas ISO 25010 ysng mencakup aspek funtional suitability, compatibility, usability, dan performance efficiency. Metode yang digunakan dalam penelitian adalah Research and Development (R\&D) dengan model waterfall. Hasil dari penelitian adalah aplikasi jadwal perkuliahan telah memenuhi standar kualitas perangkat lunak berdasarkan standar ISO 25010. Pengujian functional suitabilitymendapatkan hasil sebesar 100\% yang berarti fungsi aplikasi telah berjalan dengan benar.Pengujian compatibilitymendapatkan hasil sebesar $100 \%$. Pengujian usabilitymendapatkan hasil sebesar 79,63\% dengan kategori Layak. Pengujian performance efficiencymendapatkan rata-rata waktu launchingsebesar 2,048 detik dan 0,095 detik untuk rata-rata waktu rendering
\end{abstract}

Kata kunci: jadwal, aplikasi mobile, Android, ISO 25010

\section{PENDAHULUAN}

Dalam sebuah institusi pendidikan, misalnya perguruan tinggi, terdapat berbagai macam jadwal salah satunya adalah jadwal kuliah.Berdasarkan dari pengamatan yang dilakukan di Fakultas Teknik Universitas Negeri Yogyakarta didapatkan hasil bahwa jadwal kuliah disediakan melalui beberapa bentuk. Selain kertas, informasi jadwal kuliah juga memanfaatkan perkembangan teknologi. Seperti mulai tahun 2013, Fakultas Teknik mulai menggunakan file Portable Document
Format (PDF) melalui website fakultas untuk penyebaran informasi jadwal kuliah. Mulai tahun 2014, Sistem Informasi Akademik (SIAKAD) juga menyediakan fitur menampilkan informasi jadwal kuliah. Pemanfaatan teknologi digunakan untuk membantu mahasiswa maupun dosen mendapatkan informasi jadwal kuliah dalam memanajemen waktu dan merencanakan kegiatan kuliah yang akan berlangsung.

Berbagai jadwal kuliah yang sudah tersedia saat ini ternyata masih terdapat beberapa permasalahan dalam mendapatkan 
informasi jadwal kuliah. Oleh karena itu, diperlukan sebuah perangkat lunak untuk memperoleh, mencari dan memberitahukan informasi jadwal kuliah yang memenuhi standar kualitas perangkat lunak ISO 25010. Perangkat lunak saat ini banyak dikembangkan untuk perangkat mobile. Perangkat mobile tidak hanya digunakan untuk berkomunikasi telepon dan sms tetapi juga dapat mengakses internet. Kemampuan mengakses internet pada perangkat mobile seperti smartphone dapat digunakan untuk chatting dan mengunduh file. Selain perangkat mobile, sistem operasi juga ikut berkembang, salah satunya adalah sistem operasi android. Sehingga, penelitian ini menganalisis aplikasi jadwal perkuliahan berbasis mobile untuk platform Android berdasarkan standar kualitas perangkat lunak ISO 25010.

\section{METODE}

Penelitian ini menggunakan jenis penelitian kuantitatif untuk menganalisis kualitas Aplikasi Jadwal Perkuliahan Berbasis Android. Letak dari penelitian terdapat pada pengujian perangkat lunak yang dihasilkan pada penelitian pengembangan Aplikasi Jadwal Perkuliahan untuk platform Android. Penelitian ini dilakukan di Jurusan Pendidikan Teknik Elektronika. Subjek penelitian dimaksudkan untuk aspek functional suitability dan usability. Pengujian aspek functional suitability adalah responden ahli dalam pengembangan aplikasi. Sedangkan untuk usability adalah sample oleh setidaknya 20 responden mahasiswa yang berada dilingkungan Jurusan Pendidikan Teknik Elektronika. Sedangkan subjek penelitian untuk aspek performance efficiency dan compatibility adalah perangkat lunak yang dikembangkan, yaitu Aplikasi Jadwal Perkuliahan.

Instumen functional suitability dalam penelitian ini menggunakan checklist pada test case dan diuji oleh responden ahli dalam pengembang perangkat lunak. Test case berisi penjabaran daftar fungsi aplikasi sesuai dengan fungsi pada daftar kebutuhan pengguna.

Instrumen pada aspek compatibility dilakukan dengan menggunakan compatibility testing dari perangkat langsung, emulator Memu Player dan cloud testing dari Firebase Test Lab dan Monkop. Selain itu juga dilakukan instalasi aplikasi pada berbagai macam perangkat Android dengan sistem operasi mulai dari Android Ice Cream Sandwich hingga android Lolipop.

Instrumen yang digunakan pada aspek usability adalah kuesioner berdasarkan USE Questionnaire oleh Arnold M.Lund (2001) yang berjumlah 30 pernyataan dengan 4 kriteria, yaitu usefulness, easy of use, ease of learning dan satisfaction.

Instrumen untuk performance efficiency menggunakan perangkat pengembangan Sublime Text. Smartphone dengan koneksi internet HSDPA dari provider XL, Indosat serta wifi juga digunakan untuk pengujian secara langsung pada perangkat. Selain menggunakan perangkat secara langsung juga digunakan perangkat cloud yang disediakan oleh Firebase dan Monkop serta emulator dari Memu Player.

Aspek functional suitability diujikan menggunakan test case dengan skala Guttman sebagai skala pengukuran instrumen. Setiap jawaban item instrumen yang menggunakan skala ini harus tegas dan konsisten, seperti "Ya" atau "Tidak" (Guritno, Sudaryono, \& Rahardja, 2011:115). Analisis hasil pengujian dilakukan dengan membandingkan hasil yang diperoleh dengan kriteria yang terdapat dalam dokumen Testing Criteria for Android Applications oleh organisasi App Quality Alliance (AQuA). Kriteria yang digunakan adalah kriteria functionality sanity check dengan tingkat pengujian critical sehingga semua fungsi yang diujikan dapat lolos. Jika tidak lolos maka aplikasi tersebut secara keseluruhan dinyatakan gagal.

Aspek kualitas compatibility diujikan dengan melakukan uji coba secara operasional, yaitu menginstall aplikasi di berbagai versi 
sistem operasi Android mulai dari versi minimum Ice Cream Sandwich. Kemudian hasilnya didokumentasikan untuk dilakukan perhitungan persentase kelayakan. Hasil dari perhitungan persentase tersebut digunakan untuk mengetahui tingkat kualitas aspek compatibility pada aplikasi. Perhitungan dilakukan dengan rumus persentase kelayakan sebagai berikut:

$$
=\frac{\text { Persentase Kelayakan }}{\text { Nilai total }} \times 100 \%
$$

Analisis aspek kualitas usability dilakukanmenggunakan skala Likert. Arnold M. Lund (2001) menjelaskan bahwa skala kuesioner yang digunakan USE Questionnaire adalah skala Likert. Penelitian menggunakan skala 5 karena skala 5 poin relatif lebih cepat dan mudah digunakan dalam penelitian. Analisis kuantitatif jawaban pada skala Likert diberi skor sebagai berikut: (1) Sangat setuju (SS) diberi skor 5; (2) Setuju (S) diberi skor 4; (3) Ragu-ragu (RR) diberi skor 3; (4) Tidak setuju (TS) diberi skor 2; dan (5) Sangat tidak setuju (STS) diberi skor 1. Hasil perhitungan yang didapat, dibandingkan dengan kriteria interpretasi skor yang sudah disesuaikan. Kriteria interpretasi skor dihitung menggunakan rumus yang dapat dilihat pada Tabel 1 .

Tabel 1. Kriteria Skor Interpretasi (Jelita Ferra D, 2012)

\begin{tabular}{ll}
\hline \multicolumn{1}{c}{ Rentang Skor } & \multicolumn{1}{c}{ Kategori } \\
\hline$\sum>\mathrm{Mi}+1,8 \mathrm{Sbi}$ & Sangat Layak \\
$\mathrm{Mi}+0,6 \mathrm{SBi}<\sum \leq \mathrm{Mi}$ & Layak \\
$+1,8 \mathrm{Sbi}$ & \\
$\mathrm{Mi}-0,6 \mathrm{SBi}<\sum \leq \mathrm{Mi}$ & Cukup Layak \\
$+0,6 \mathrm{Sbi}$ & \\
$\mathrm{Mi}-1,8 \mathrm{SBi}<\sum \leq \mathrm{Mi}-$ & Kurang Layak \\
$0,6 \mathrm{Sbi}$ & \\
$\sum \leq \mathrm{Mi}-1,8 \mathrm{Sbi}$ & Sangat Tidak \\
\hline
\end{tabular}

Keterangan:

$$
\begin{array}{ll}
\Sigma & =\text { Skor akhir rata-rata } \\
\mathrm{Mi} & \text { Mean ideal } \\
\mathrm{Sbi} & \text { Simpangan baku ideal } \\
\text { Rumus Mi }= & 1 / 2 \text { (skor tertinggi }+ \text { Skor } \\
& \text { terendah) } \\
\text { Rumus SBi }= & (1 / 2)(1 / 3)(\text { Skor maks. }- \text { skor } \\
& \text { min.) }
\end{array}
$$

Aspek kualitas performance efficiency diujikan dengan menghitung rata-rata waktu respon aplikasi untuk launhing dan rendering. Hasil yang diperoleh dibandingkan dengan tabel kepuasan pengguna seperti pada Tabel 2 . Menurut Hoxmeier dan DiCesare (2000), pengguna mendapatkan kepuasan tinggi jika waktu respon dalam kondisi delay 0 detik sedangkan kepuasan tetap dalam rentang 3 sampai 9 detik dan mengalami penurunan bila lebih dari 12 detik. Dan jika hasil dari perhitungan rata-rata waktu respon kurang dari 9 detik maka aplikasi yang dikembangkan memenuhi aspek ini

Tabel 2. Pengukuran Kepuasan Pengguna (Hoxmeier \& DiCesare, 2000)

\begin{tabular}{ll}
\multicolumn{1}{c}{$\begin{array}{c}\text { Respon waktu } \\
\text { (detik) }\end{array}$} & \multicolumn{1}{c}{ Predikat } \\
\hline$<3$ & Sangat puas \\
$3-9$ & Puas \\
$9-12$ & Cukup puas \\
\hline
\end{tabular}

\section{HASIL}

Berdasarkan dari hasil perhitungan yang dilakukan untuk pengujian functional suitability, diperoleh persentase aspek functional suitability untuk fungsi-fungsi pada aplikasi jadwal perkuliahan, yaitu $100 \%$. Hasil perhitungan persentase dengan kriteria yang terdapat dalam dokumen Testing Criteria for Android Applications oleh organisasi App Quality Alliance (AQuA) (2014).Berdasarkan perbandingan yang dilakukan, dapat 
disimpulkan bahwa semua fungsi aplikasi dapat berjalan dengan benar.

Pengujian compatibilitydilakukan dengan menggunakan menginstalasi pada perangkat dan menjalankan aplikasi pada perangkat. Perangkat yang tersedia berjumlah 22 perangkat Hasil dari pengujian dapat dilihat pada Tabel 3 .

Tabel 3. Hasil Pengujian Compatibility

\begin{tabular}{ccccc}
\hline No. & Pengujian & Berjalan & Gagal & Nilai \\
\hline 1. & Instalasi pada perangkat & 22 & 0 & 22 \\
2. & Menjalankan aplikasi pada & 22 & 0 & 22 \\
& perangkat & 44 & 0 & 44 \\
& Total & & $\frac{44}{44} \times 100 \%=100 \%$ & \\
\hline
\end{tabular}

Berdasarkan hasil pengujian compatibility pada Tabel 3, diperoleh hasil bahwa instalasi pada semua perangkat berhasil berjalan dengan persentase $100 \%$ dan tidak muncul pesan kesalahan. Maka dapat disimpulkan bahwa aplikasi jadwal perkuliahan telah memenuhi standar aspek compatibility.

Berdasarkan pada perhitungan persentase dari pengujian usability yang dilakukan didapatkan hasil sebesar 79,63\% yang kemudian dicocokan dengan Kriteria Interpretasi Skor dan mendapatkan interpretasi layak.

$\begin{array}{ccr}\text { Hasil waktu launching aplikasi } & \text { waling lama }\end{array}$ membutuhkan $4884 \mathrm{~ms}$ dan tercepat $590 \mathrm{~ms}$ dengan rata-rata waktu $2084 \mathrm{~ms}$. Sedangkan untuk waktu rendering aplikasi membutuhkan waktu paling tinggi 410ms dengan waktu tercepat $14 \mathrm{~ms}$. dengan rata rata waktu $95 \mathrm{~ms}$. Berdasarkan hasil kedua pengujian tersebut didapatkan rata-rata 2,084 detik dan 0,095 detik. Dari hasil tersebut kemudian dibandingkan dengan Tabel 2 dan diperoleh hasil dengan predikat sangat puas. Sehingga dapat disimpulkan bahwa Aplikasi Jadwal Perkuliahan sudah memenuhi standar aspek performance efficiency. Semakin cepat pengguna dapat mengakses informasi pada Aplikasi Jadwal Perkuliahan, semakin efisien waktu yang digunakan pengguna untuk mendapatkan informasi.

\section{SIMPULAN}

Berdasarkan hasil penelitian dan pembahasan yang dilakukan, dapat disimpulkan bahwakualitas aplikasi mobile jadwal perkuliahan telah memenuhi standar kualitas perangkat lunak berdasarkan standar ISO 25010. Aplikasi mobile jadwal perkuliahan diuji dengan mencakup empat aspek, yaitu funtional suitability, compatibility, usability, dan performance efficiency dengan hasil pengujian functional suitability sebesar $100 \%$, pengujian compatibility sebesar $100 \%$, pengujian usability sebesar $79,63 \%$ dengan kategori layak, dan pengujian performance efficiency sebesar 2,048 detik untuk waktu launching dan 0,0095 detik untuk waktu rendering dengan predikat sangat puas. Berdasarkan kesimpulan serta keterbatasan produk pada penelitian ini, peneliti memberikan saran untuk pengembangan yang akan datang sebagai berikut: (1) Aplikasi dikembangkan untuk platform yang berbeda seperti iOS atau Windows Phone; (2) Mengimplementasikan fitur yang belum ada, seperti dapat diakses ketika offline; dan (3) Menambahkan halaman admin untuk mengelola data. 


\section{DAFTAR PUSTAKA}

App Quality Alliance. 2014. AQuA Performance Testing Criteria. Diakses pada 15 Februari 2017. Dari http://www.appqualityalliance.org/aqu a-performance-test-criteria.

Ferra Delan, Jelita. 2012. Pengembangan Website Petunjuk Praktikum Kimia untuk Peserta Didik SMA/MA Kelas XII Semester 1.S1 thesis, Universitas Negeri Yogyakarta.

Guritno, S., Sudaryono, \& Rahardja, U. 201). Theory and Application of IT Research Metode Penelitian Teknologi Informasi. Yogyakarta: Andi
Hoxmeier, J. A., \& DiCesare, C. 2000. System Respone Time and User Satisfaction: An Experimental Study of Browser-based Applications. AMCIS 200 Proceedings. Diakses pada 26 April 2017.2 Dari http://www.collecter.org/archieves/200 0_April/03.pdf.

Lund, A. M. 2001. Measuring Usability with USE Questionnaire. Usability and User Experience SIG. Diakses pada 28 Februari 2017. Dari http://www.stcsig.org/usability/newslett er/0110_measuring_with_use.html 